\title{
Scaffolding Teaching Design of College English Based on Constructivism
}

\author{
Hui-Min ZHAO ${ }^{1, a}$ \\ ${ }^{1}$ Teaching and Research Institute of Foreign Languages, Bohai University, Jinzhou 121013, China \\ ahmzhao2008@163.com
}

Keywords: Constructivism, Scaffolding Teaching, Teaching Design.

\begin{abstract}
The development of social economy puts forward higher demand for English personnel. Traditional college English teaching mode has low efficiency and leads to the deficiency of comprehensive ability for students. The scaffolding teaching method based on constructivism can improve the learning autonomy of students as well as the comprehensive application ability. The author applies the scaffolding teaching to college English teaching and explores the specific application strategy of scaffolding teaching. The author hopes it can be helpful to the English teaching reform.
\end{abstract}

\section{Introduction}

With the development of social politics and economy, the social demands for English personnel are changing. The social demands transit from the traditional demands for English knowledge to the demands for English ability. That is, the job market is no longer satisfied with the personnel having English knowledge, but demands the personnel possessing higher comprehensive ability. Namely, the college students should possess the comprehensive ability such as listening, speaking, reading and writing. The changing of social demand makes the college English teaching adjust correspondingly. The classroom teaching mode changes from the original knowledge teaching into ability training. However, the college English teaching mode still remains in the traditional teaching mode, the teacher teaches and students passively accept. So the students' learning initiative is not high and the learning efficiency is not high, and the students even are weary of learning English. It has become the focus of reform of college English teaching that how to change the traditional teaching mode, improve the class participation degree of students, activate the students' learning initiative and train the comprehensive English ability of students. The college English scaffolding teaching mode based on constructivism can solve the above problems quite well and improve the students' English learning efficiency and achieve the active construction of knowledge.

\section{Theory of Constructivism and Scaffolding Teaching}

Constructivism is an important branch of cognitive theory. Constructivism was first proposed by Piaget, a Swiss psychologist, who studied the cognitive rules of children. Later, it absorbed the theory of "zone of proximal development" proposed by L. Vygotsky and the theory of meaningful receptive learning proposed by D. Ausubel. [1] Therefore, it can better reveal the cognitive rules of the learning process. Constructivism believes that learning is an active, conscious self organization of knowledge. Learning is not a simple transfer of knowledge from teachers to students, but the process of constructing the knowledge by students themselves. The students do not passively accept the information, but actively construct the knowledge and meanings. This construction can not be replaced by others. Learning is not the passive receiving of information, but the active construction of meaning. It is based on the experience of background and the students actively select and handle the information, so as to get its own meaning.

Constructivism advocates that learning should be conducted under the guidance of teacher and the learner should be centered. That is, it not only emphasizes the students' rule in cognition, but also the 
guidance of teacher. The teacher is not the indoctrinator and instructor of knowledge, but the helper and facilitator of meaning construction. Students are not the passive recipients of information, but the main body of information processing and the active constructor of meaning. Constructivism holds that knowledge should be obtained through meaning construction, under certain situation, and by the helps of others. The ideal learning environment should include context, cooperation, communication and meaning construction. (1)Learning should be under some context. The context of learning must be helpful to the meaning construction of learner. In the teaching design, the most important part is to create the context facilitating the meaning construction.(2)Cooperation should run through the whole learning process. The cooperation includes the collection and analysis of learning material, hypothesis and verification, self feedback and learning evaluation. It is between teacher and students as well as students and students. Collaboration mainly includes self collaboration and mutual collaboration. During learning, self collaboration denotes that one decides the learning things by oneself. Mutual collaboration denotes the group discussion and debate. (3)Communication is the basic way of collaboration. During collaboration, the members must discuss how to complete the learning tasks and obtain the help or guidance form teachers by communication. In fact, collaborative learning is the process of communication. In the process, each learner shares his ideas with others. Communication is the most important tool to promote the learning process of each student. (4) Meaning construction is the ultimate goal of teaching. The construction of meaning refers to the inner relation between the nature and its law. To help the students construct meaning is to help students to understand the intrinsic link between the nature and the laws.

Scaffolding teaching is an important part of the learning theory of constructivism. This kind of teaching idea is derived from the zone of proximal development theory proposed by the Soviet psychologist L. Vygotsky.[2] Vygotsky thinks that in the children's intelligence activities, some differences exist between the problems to be solved and the original ability. By teaching, children can eliminate the differences with the help of the teachers. The difference is "the zone of proximal development". Scaffolding teaching is the teaching method based on the theory of constructivism. According to this method, the learner should be centered in learning and the teaching goal is to cultivate the ability of solving problems as well as the autonomous learning ability for students. The teaching method is to provide the students with appropriate clues or prompt step by step. It lets the student climb the hills of knowledge through scaffold provided by the teacher, and gradually discovers and solves the problems in learning, and masters the knowledge and improves the ability of solving problems. Eventually, it cultivates the students to be an independent learner.

\section{Scaffolding Teaching Design of College English}

According to the teaching view of constructivism, college English teaching should be student-centered. That is, students are the subject of learning and it should fully play the initiatives of students. Teacher plays the role of assistant in students' learning. Teacher should know the possible learning obstacles of students and provides help timely. According to the above requirements, we put forward the specific scaffolding teaching design. That is, the teaching class should consist of five parts: preparation stage, context teaching, independent exploration, collaborative learning, and evaluation. We take "Time-Conscious American" in Unit one of "New Horizon College English"(the second version) as an example to explain the scaffolding English teaching.

(1) Preparation stage. That is, the teacher puts up the scaffolds for students. At this stage, the teacher should know about the English level of students as well as the most possibly developing regions. Then the teacher builds the scaffolds between two areas. Namely, the teacher puts forward the questions on the content that will be learned behind, and asks the students to prepare for these questions. This makes the students realize that new knowledge is needed to solve the questions and these knowledge needs more attention. For example, before the class of "Time-conscious American", the teacher asks the students to listen to the English talk about the time concept of Americans. In this talk, different Americans express their own views on time. Then the teacher asks the questions: What 
precious resources do American value? What is considered to be a waste of time in the US? And then the teacher asks the students to discuss in groups. Each representative of groups speaks on the questions. Then the teacher further asks the question: What do you think of time-conscious American? Then the teacher asks the students to talk about their own views on time. These views are not necessarily positive, and they can also be negative. This can foreshadow the cultural difference behind. Then the teacher explains the difference between American and Chinese cultures. This difference can be further illustrated when the students read the text.

(2) Context teaching. At this stage, the teacher brings the students a certain context of question. Constructivism emphasizes that real context should be provided in the teaching class and the insipid teaching should be changed into stereo English teaching. In the college English teaching, the teacher should create the scene of activities for the students by following the pertinent, interesting and creative principle. In the classroom teaching, the teacher designs a conversation between American and Chinese merchants. In the conversation, the American merchant talks the business with the Chinese merchant. The Chinese merchant proposes to go to restaurant and talk the business after meal. While the American merchant persists that they should talk the business now. Then the Chinese merchant is very displeased and he thinks that the American merchant have no sincerity and cancels the talk of business. Then the teacher asks the students to do the role playing. The teacher writes the new words in the blackboard that are possibly used in the dialogue. Then the teacher asks the role players to express their own ideas on the conversation. Then the teacher asks the students to think about the following questions: "Why is the Chinese businessman displeased with the American merchant? If you are the businessman, how do you deal with the case?" Then the teacher asks each group of students to comment on the dialogue.

(3) Independent exploration. The teacher lists the issues related to text and these issues are ordered according to the significance. Then the teacher asks the students to explore learning independently and complete the learning task. At the beginning, the teacher should inspire the students by providing some hints and guide them to think about the tasks. Then the students are asked to analyze the questions. During the exploration, the teacher should provide some hints on the questions timely and help the students gradually proceed along the conceptual framework. For example, the teacher arranges the learning tasks for the students such as: What is the time view of Americans? Why do Americans like fast food and talk on the phone? The teacher asks the students to summarize the different view between American and Chinese. At the same time, the students are asked to find the new sentence patterns and grammatical structures. For example, "Normally, Americans do not assess their visitors in such relaxed surroundings over extended small talk; much less do they take them out for dinner, or around on the golf course while they develop a sense of trust." This complex sentence consists of two parallel sentences and it describes the American time concept using two negative sentences. And the later parallel sentence is inverted. Then the teacher asks the students to read through the text and find the answers by themselves. The teacher asks the students to answer the questions separately and checks their completion of task. In the independent exploration stage, students are asked to learn the new words and sentences and grammar structures. The students solve the problem independently by searching the network and reference books. In this stage, the teacher should avoid asking the students to do too complex learning tasks. If the tasks are too complex, the students can not complete them. This will reduce the self efficacy of students.

(4) Collaborative learning. It is used to solve those questions that can not be solved by individual alone, such as complex sentences, difficult grammar. In collaborative learning, the teacher divides the students into several groups and each group discusses and consults the questions to find the solution. As for grammar problems, the students use the new grammar to make sentences and their group members will check the default of sentences. At the same time, the group will discuss the problems of each member. The key of collaborative learning is to make students learn in team and study the knowledge from others that they do not understand. At the same time, the students are encouraged to express their own ideas by group discussion. By group discussion, the students can realize their inadequacy of ideas, thus improves the understanding of knowledge[3]. 
(5) Effect evaluation. Evaluation of scaffolding teaching includes students' self evaluation and group evaluation. The content of evaluation includes whether the students complete the learning tasks left by the teacher, whether the students construct the meaning of knowledge, whether they contribute to the group learning and whether their autonomous learning ability is lifted. For example, in learning of "Time-Conscious American", effect evaluation includes the completion of testing cloze in textbook, the understanding of new grammar structure as well as the content of text, and the application ability of making sentence with new words[4].

\section{Conclusion}

Scaffolding teaching mode can well solve the low-efficiency problems encountered by current college English teaching. Scaffolding teaching is student-centered and leads the students to construct the knowledge structure towards the zone of proximal development. This can help the students gradually grasp and understand the knowledge. At the same time, scaffolding teaching make the students learn independently and collaboratively. This cultivates the students' awareness of collaboration and improves their autonomous learning ability.

\section{Acknowledgement}

This work is part of the project of Research on Task-based English Teaching Mode Based on Constructivism Theory. The work has been supported from the fund of Liaoning Provincial Federation Social Science Circles (No. 2015lslktziwx-03), and also from the fund of Liaoning Planning Office of Philosophy and Social Sciences (L13CYY018).

\section{References}

[1]D.P. Ausubel, Educational Psychology: A Cognitive View. Holt: Rinehart \& Winston, 1978.

G. Wells, Dialogic Inquiries in education: Building on the legacy of Vygotsky. Cambridge University Press, 1999, pp. 57

[2]R. Ellis, Task-based Language Learning and Teaching. Oxford: Oxford University Press, 2003.

[3]P. Blanche, Self-assessment of foreign language skills: implications for teachers and researchers, RELC Journal 19 (1988) 75-95. 